\title{
Gerakan Literasi Matematika Bagi Siswa untuk Peningkatan Kemampuan Berpikir Kreatif di SDN Kenari 07 Pagi
}

\author{
Mathematics Literacy Movement for Students to Increase Creative Thinking Ability at SDN \\ Kenari 07 Pagi
}

\author{
1) Alberth Supriyanto Manurung, ${ }^{2)}$ Abdul Halim, ${ }^{3)}$ Ainur Rosyid \\ 1,2,3 FKIP, Universitas Esa Unggul \\ *Email: alberth@esaunggul.ac.id
}

\begin{abstract}
ABSTRAK
Matematika adalah ilmu tentang logika mengenai bentuk, susunan, besaran dan konsep berhubungan satu sama lain. Dalam konsepnya selalu berhubungan dengan kehidupan manusia sehari-hari. Belajar Matematika dalam bentuk Gerakan Literasi siswa bukan hanya sekedar meningkat rasa ingin tahu tapi selalu berkembangnya kemampuan berpikir kreatif, mata pelajaran Matematika adalah ilmu menghitung yang bertujuan untuk menanamkan dan mengembangkan proses hitungan pada guru.Berdasarkan hasil observasi di SDN Kenari 07 Pagi pada proses pembelajaran guru masih menggunakan cara mengajar yang konvensional atau berpusat pada guru sebagai pemberi informasi, dengan adanya gerakan literasi siswa diharapkan meningkatkan kualitas yang baik dari setiap konsep pengerjaan masalah dalam bentuk aplikasi soal.
\end{abstract}

Kata Kunci : Gerakan, Kemampuan, kreatif, Literasi, Matematika

\section{ABSTRACT}

Mathematics is the science of logic regarding forms, structures, quantities and concepts related to one another. In the concept it is always related to everyday human life. Learning Mathematics in the form of the Student Literacy Movement is not only an increase in curiosity but always the development of creative thinking skills, Mathematics is the science of calculating which aims to instill and develop a counting process in teachers. Based on the results of observations at SDN Kenari 07 Pagi on the teacher learning process still using conventional or teacher-centered teaching methods as information providers, with the student literacy movement it is expected to improve the good quality of each problem-solving concept in the form of question applications.

Diterima : 16-11-2020 Disetujui :30-11-2020 Dipublikasikan : 30-12-2020

\section{PENDAHULUAN}

SDN Kenari 07 Pagi merupakan sekolah negeri dengan kepemilikan Pemerintah Pusat dan berada dalam pembinaan Suku Dinas Pendidikan Wilayah Jakarta Pusat. Berdiri dengan SK Pendirian tertanggal 1981-08-19, SK Izin Operasional tertanggal 1910-01-01 dan Nomor Pokok Statistik Nasional (NPSN) 20100539. Gedung sekolah berdiri di atas lahan milik sendiri seluas $4488 \mathrm{~m}^{2}$ dan status akreditasi sekolah B.
Sekolah ini mempunya visi terwujudnya peserta didik yang cerdas, terampil, berbudi pekerti luhur berdasarkan iman dan takwa. Sementara beberapa misinya antara lain, 1) melaksanakan pembelajaran dan bimbingan secara efektif sehingga setiap siswa berkembang secara optimal dengan potensi yang dimiliki, 2) mendorong dan membantu setiap siswa untuk mengenal potensi diri, 3) menumbuhkan semangat belajar secara intensif kepada seluruh peserta didik, 4) menumbuhkan penghayatan dan 
pengamalan terhadap ajaran agama dan budaya bangsa.

Dalam pengelolaannya, sekolah difasilitasi dengan kondisi standar dan mencakup ruang kelas (19), ruang kepala sekolah (1), ruang guru (1), ruang tata usaha (1), ruang UKS (1), ruang ibadah/mushola (1), perpustakaan (2), ruang literasi (1), laboratorium IPA (1), laboratorium agama (1), toilet siswa (24), toilet guru (12), kantin sekolah (5), gudang (2), aula sekolah (1), dan lapangan upacara (1). Kondisi fasilitas yang kurang baik berkaitan dengan instalasi air, jaringan internet, beberapa lantai kelas yang mulai rusak, dan beberapa lampu yang kurang terang cahayanya . Sementara itu, fasilitas laboratorium komputer dan laboratorium bahasa belum ada. Fasilitas internet tersedia sebatas ruang administrasi ketatausahaan.

Penyelenggaraan sekolah adalah 5 hari kerja dengan beberapa program pembiasaan yang dilakukan setiap harinya. Adapun program pembiasaan tersebut antara lain, Senin (upacara bendera), Selasa (senam bersama untuk siswa kelas 1-3), Rabu (doa bersama), Kamis (senam bersama untuk siswa kelas 4-6). Jam belajar untuk kelas 1 dan 2 hanya sampai pukul 10.45 WIB, sedangkan kelas 3-6 sampai pukul 12.10 WIB.

Sekolah ini dikelola oleh 22 guru yang terdiri dari 15 Guru Tetap/PNS, 0 guru bantu CPNS, 0 guru CPNS K2, 0 guru KKI -UMP K2, dan 7 guru KKI-UMP. Sekolah ini juga diperbantukan oleh 4 tenaga tata usaha dan 3 penjaga sekolah. Data statistik lain menunjukkan pemenuhan rasio kelas : siswa adalah 1 : 32 yang dialokasikan dalam 16 rombongan belajar (rombel). Rombel tersebut terdiri atas pengelompokan 3 rombel kelas I (91 siswa), 3 rombel kelas II (93 siswa), 3 rombel kelas 3 (95 siswa), 2 rombel kelas IV (63 siswa), 3 rombel kelas V (94 siswa), dan 3 rombel kelas VI (78 siswa).
Sekolah Kenari 07 Pagi merupakan sekolah inklusi. Hampir tiap kelas memiliki siswa berkebutuhan khusus yang berkisar antara 2-4 siswa. Dalam hal pembelajaran di kelas, tentu guru memiliki perlakuan khusus yang disesuaikan dengan kemampuan siswa inklusi tersebut. Meski kebutuhan khusus yang dimiliki siswa berbeda-beda, dominan dari mereka memiliki keterbatasan dalam hal menyerap pelajaran di kelas (siswa lambat belajar). Namun dari sisi sosial, para siswa di sekolah ini mampu untuk berbaur satu sama lain dan saling menghormati. Jika dilihat berdasarkan latar belakang ekonomi, kebanyakan siswa berasal dari keluarga berlatar ekonomi menengah ke bawah. Berikut merupakan beberapa gambaran mengenai kondisi dan situasi di SDN Kenari 07 Pagi.

Dalam kaitannya dengan pengembangan literasi matematika, berdasarkan hasil wawancara dengan kepala sekolah, guru, beberapa siswa, dan observasi peneliti, ditemukan beberapa permasalahan yang dihadapi sekolah ini. Permasalahan tersebut berkaitan dengan kurangnya kemampuan siswa untuk memahami isi teks bahasa Indonesia yang terdapat dalam buku pelajaran, kurangnya pemahaman siswa untuk memaknai berbagai istilah yang muncul dalam lambang matematika(Manurung. S. Alberth, 2015), keterbatasan lambang matematika yang dimiliki siswa ketika menjelaskan suatu konsep atau makna dari suatu bacaan, media literasi yang digunakan guru kurang membangkitkan motivasi siswa untuk membaca, serta kurangnya rasa percaya diri siswa ketika menjelaskan isi teks yang sudah dibacanya(Desmita, 2010).

Atas dasar itulah program pengembangan literasi matematika menjadi penting untuk dilakukan. Meski beberapa permasalahan dominan berasal dari siswa, instruktur melihat bahwa peran guru juga penting(Siti Aisyah, Adelina Hasyim, 2014). Agar siswa termotivasi untuk memaksimalkan 
kemampuan berpikir kreatif dan mengembangkan literasi matematika, guru perlu memiliki bekal yang lebih banyak lagi sebelum mengajarkan materi-materi matematika di kelas. Salah satu upaya yang perlu dilakukan adalah dengan menerapkan beberapa permainan tradisional sebagai media pengembangan literasi matematika di kelas. Media tersebut diharapkan dapat mendorong kemampuan berpikir kreatif siswa untuk memperkaya kemampuan literasi matematika di SDN Kenari 07 Pagi.

Mengacu pada analisis situasi dimuka, untuk melaksanakan gerakan literasi matematika bagi siswa, dapat diidentifikasi berbagai masalah yang sangat berpengaruh signifikan terhadap isu masalah berikut ini. Mitra yang akan dilibatkan dalam kegiatan ini adalah SDN Kenari 07 Pagi. Sekolah tersebut berada di Kelurahan Kenari, Kecamatan Senen Kota Jakarta Pusat. Jarak lokasi mitra dari Universitas Esa Unggul lebih kurang 15 $\mathrm{km}$. Berdasarkan informasi yang didapat dari kepala sekolah dan guru kelas di SDN Kenari 07 Pagi, hampir 70\% siswa kelas tinggi terutama yang perempuan memiliki kemampuan berpikir kreatif yang rendah untuk meningkatkan prestasi. Secara keseluruhan jumlah siswa laki-laki adalah 249 orang dan siswa perempuan ada 265 siswa yang dibantu oleh sebanyak 10 guru laki-laki dan 12 guru perempuan. Beberapa guru pernah mendapat kesempatan untuk mengikuti kegiatan-kegiatan peningkatan kualitas pembelajaran. Namun, sosialisasi dan aplikasi pengetahuan yang diperoleh kurang maksimal dilakukan. Bahkan beberapa sumbangan baik media maupun buku jarang digunakan dalam proses pembelajaran di sekolah dengan alasan kurangnya pendampingan.

Sebenarnya dalam pembelajaran perlu dilakukan inovasi untuk meningkatkan hasil belajar sehingga dapat menumbuhkan sikap positif anak dalam belajar. Perlu juga dilakukan kegiatankegiatan yang dapat meningkatkan pemahaman dan keterampilan guru dalam melakukan inovasi pembelajaran. Sebagai bagian dari perguruan tinggi yang menghasilkan guru, maka perlu untuk lebih pro aktif melakukan kegiatan yang memberi manfaat positif bagi guru. Oleh karena itu perlu dilakukan program atau kegiatan membangun paradikma seorang guru.

Masalah spesifik yang benar-benar dihadapi kelompok usaha (mitra) dalam jangka pendek, antara lain:

1. Masalah variasi rumusan yang kurang banyak sehingga guru tidak mendapat penyelesaian dengan alternatif yang berbeda.

2. Minimnya pengetahuan tentang gerakan literasi matematika.

Untuk menyelesaikan permasalahan tersebut, maka pengusul mencoba membuat pelatihan cara memahami gerakan literasi matematika secara efektif dan berjenjang.

Kegiatan Solusi yang ditawarkan melalui kegiatan ini adalah membimbing dan melatih siswa-siswa siswa sekolah dasar memberikan kemampuan berpikir kreatif yang baik saat awal pembelajaran maupun akhir pelajaran sehingga menumbuhkan sikap positif dari dalam diri siswa. Dampak yang diharapkan dari kegiatan ini adalah terbentuknya kebiasaan memberikan kemampuan berpikir kreatif pada siswa di sekolah mitra, dengan cara membiasakan diri memberi cerita yang positif dengan mengambil contoh masyarakat yang berhasil pada bidang tertentu. Dimana setiap hari guru wajib memberikan inspirasi yang positif dalam mendampingi dan membimbing siswa sehingga muncul diskusi kecil diantara siswa kemudian tiap siswa menjelaskan makna motivasi yang diberikan guru tersebut.

Sasaran dalam kegiatan ini adalah siswa-siswa sekolah dasar. Pertama sekali siswa-siswa dilatih untuk mengetahui Peranan kemampuan berpikir kreatif dalam 
belajar dan menumbuhkan kreatif dalam pembelajaran. Langkah awal mengetahui peranan kemampuan berpikir kreatif adalah: (1) menemukan hal-hal yang dapat dijadikan penguat belajar; (2) memperjelas tujuan belajar yang hendak dicapai; (3) menentukan ragam kembali terhadap rangsangan belajar; (4) menentukan ketekunan belajar. Dalam hal ini seseorang siswa yang belajar dihadapkan pada suatu masalah yang memerlukan pemecahan, dan hanya dapat dipecahkan berkat bantuan hal-hal yang pernah dilaluinya. Siswa akan tertarik untuk belajar sesuatu, jika yang dipelajari itu sedikitnya sudah dapat diketahui atau dinikmati manfaat bagi siswa dan peranan kemampuan berpikir kreatif terakhir adalah berusaha mempelajari dengan baik dan tekun, dengan harapan memperoleh hasil yang baik. Langkah berikutnya adalah memberi pelatihan menumbuhkan kemampuan berpikir kreatif dapat juga dikaitkan dengan proses belajar mengajar di sekolah hal ini turut mempengaruhi dorongan rasa keinginan tahun siswa guna merespon segala permasalahan yang timbul di sekolah(Dale, 2012). Hal yang terpenting untuk menumbuhkan rasa motivasi siswa adalah peran aktif guru untuk membangkitkan semangat siswa sehingga diharapkan terjadi hal-hal yang positif terjadi. Siswa yang kreatif sering menjadi inspirasi siswa yang lain sehingga menambah pengalaman siswa karena apa yang diperhatikan tentu membangkitkan kemampuan berpikir kreatif sejauh apa yang dilihat itu mempunyai hubungan dengan kepentingan dirinya sendiri sehingga menimbulkan tindakan secara langsung. Kegiatan memberikan kemampuan berpikir kreatif melibatkan semua siswa dalam satu kelas. Instruktur menceritakan berbagai orang yang menginspirasi dan melibatkan siswa selama proses pembelajaran dengan memberi kesimpulan makna dibalik cerita yang menginspirasi. Kegiatan ini dilakukan di kelompok kecil beranggotakan siswa dengan anggota beberapa siswa. Di awal program, instruktur mengidentifikasi siswa yang kurang kemampuan berpikir kreatif kemudian mengelompokkannya. Instruktur memilih dan memperkenalkan sesuatu yang menginspirasi serta membimbing(Ediyanto et al., 2020) setiap siswa dalam memaknai dan memahami hal yang menginspirasi. Bimbingan diberikan selama kegiatan berlangsung baik sebelum, saat, dan setelah memberi hal yang menginspirasi, awal pelaksanaan pelatihan penerapan kemampuan berpikir kreatif(Wanelly and Fauzan, 2020), guru disarankan menggunakan semua kelompok selama satu semester. Hal ini dimaksudkan untuk membantu guru mengenali dan memahami proses pelaksanaan kegiatan tersebut.

\section{METODE}

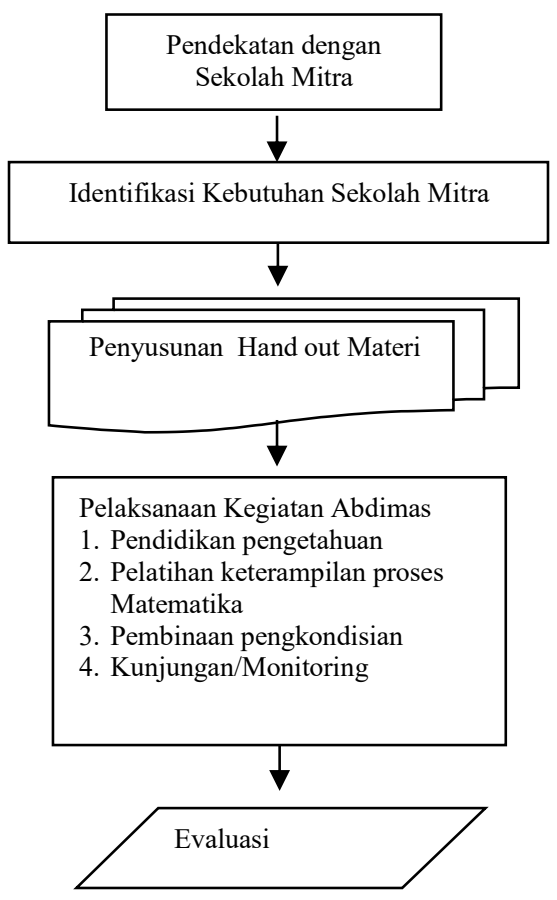

HASIL DAN PEMBAHASAN

Hasil pengabdian terdiri dari hasil Metode pendekatan untuk mendukung 
Pelatihan Gerakan Literasi siswa dalam Peningkatan kemampuan berpikir kreatif di SDN Kenari 07 Pagi meliputi:

1) Pendekatan teori singkat (Workshop): Dalam hal ini PT mengumpulkan pendidik untuk melakukan pelatihan Gerakan Literasi siswa dalam Peningkatan kemampuan berpikir kreatif sehingga memperoleh wawasan pendahuluan.

2) Pendekatan aplikasi lapangan

PT melakukan bimbingan dilapangan kepada seluruh mitra secara bertahap yang diwujudkan dari teori ke aplikasi.

3) Pendekatan evaluasi

Dalam hal ini PT melakukan survey lapangan untuk memperoleh seberapa efektif pelatihan yang telah dilaksanakan.

Pendekatan ini untuk memperoleh gambaran terhadap kendala yang dihadapi mitra yang pada akhirnya para mitra diminta agar membuat laporan progres, sehingga dapat digunakan dalam perbaikan dan pengembangan.

Setelah menyusun rencana kegiatan selama 1 bulan dilanjutkan pemberian laporan setelah empat bulan selesai pelatihan Gerakan Literasi siswa untuk Peningkatan kemampuan berpikir kreatif. Dalam kegiatan ini diharapkan partisipasi mitra adalah sebagai berikut:

1. Mitra terdaftar sekurang-kurangnya 30 Peserta, dan yang mengikuti workshop diharapkan $100 \%$.

Dari kegiatan ini diharapkan mitra selalu berinteraksi dan mendiskusikan berbagai masalah yang dihadapi oleh setiap mitra, sehingga pelatih dapat memberikan solusinya melalui landasan teori.

2. Dalam bimbingan lapangan, diharapkan dapat dibimbing $100 \%$

Dalam bimbingan ini diharapkan mitra berpartisipasi dalam menyampaikan masalah, sehingga dapat diatasi secara langsung secara bertahap kepada masing-masing mitra.

Dengan bimbingan ini, mitra diharapkan memperoleh kemudahan mengerjakan dan menyelesaikan Gerakan Literasi siswa dalam meningkatkan motivasi berprestasi(Sudestia Ningsih, 2016).

3. Dalam kegiatan evaluasi, diharapkan PT dapat memperoleh progres pelatihan Gerakan Literasi siswa dalam meningkatkan motivasi berprestasi yang diajarkan pada peserta didik dan membuat laporan secara lengkap tentang progres dari berbagai kegiatan yang telah dilakukan.Dengan menerima laporan lengkap dari berbagai kegiatan yang dilakukan oleh pendidik, dapat disimpulkan bahwa berapa persen dapat berhasil dan berapa persen yang kurang berhasil.

Dari hasil analisis ini dapat diketahui teknis apa yang akan digunakan untuk memenuhi kebutuhan sendiri mitra(Demitra, 2012). Manfaat yang akan dihasilkan adalah peserta didik dapat memahami Gerakan Literasi siswa dengan cara yang efesien dan efektif. Teknologi yang digunakan cukup sederhana sehingga meminimalisasi biaya yaitu dengan mengunakan bahan yang ada di sekitar sebagai contoh dalam mengaplikasikan Gerakan Literasi siswa.

\section{SIMPULAN}

Kegiatan pelatihan Gerakan Literasi siswa dalam Peningkatan kemampuan berpikir kreatif di SDN Kenari 07 Pagi dapat berjalan dengan lancar. Semua peserta terlihat antusias dan merasakan manfaatnya. Keberhasilan ini ditunjukkan antara lain:

1. Dalam penyampaian materi oleh seorang guru juga akan sangat berpengaruh terhadap pembelajaran siswa yang diajar.

2. Kecerdasan seorang guru Sekolah Dasar dalam menyampaikan materi perlu didukung oleh peran orang tua murid. 
3. Para orang tua murid perlu diberikan suatu tindakan yang berguna mempermudahkan siswa menambah informasi pelajaran yang sedang berlangsung.

4. Peserta didik diharapkan aktif bertanya pada saat mengalami kesulitan dalam menyelesaikan kebiasaan Gerakan Literasi Siswa.

Sehubungan dengan kegiatan diatas maka saran yang dapat diajukan adalah :

Karena adanya peningkatan kemampuan berpikir kreatif yang signifikan dari penggunaan pengajaran ini maka disarankan kepada guru hendaknya lebih mempertimbangkan penggunaan pendekatan kemampuan berpikir kreatif, sebagai salah satu metode yang perlu dikembangkan dalam proses belajar mengajar.

\section{DAFTAR PUSTAKA}

Dale (2012) Learning Theories an Education Perspective. Yogyakarta:

Pustaka Pelajar.

Demitra, S. (2012) 'Pengembangan Model Pembelajaran Kooperatif Handep Untuk Pembelajaran Matematika', JURNAL PENDIDIKAN DAN PEMBELAJARAN, 19(1).

Desmita (2010) Psikologi perkembangan peserta didik. Bandung: Rosda Karya. Ediyanto, E. et al. (2020) 'Pengaruh Pendekatan Realistic Mathematics Education Terhadap Motivasi Dan Hasil Belajar Materi Matematika Di Sekolah Dasar', Jurnal Basicedu, 4(1), pp. 203-209. doi: 10.31004/basicedu.v4i1.325.

Manurung. S. Alberth (2015) 'Hubungan Antara Motivasi Berprestasi Terhadap Hasil', EDUSCIENCE, 1(1).

Siti Aisyah, Adelina Hasyim, R. R. (2014)

'PENGEMBANGAN MODEL PEMBELAJARAN KOOPERATIF LEARNING TIPE MAKE A MATCH Jurnal Teknologi Informasi Komunikasi
Pendidikan Vol 2, No 3 (2014) Riswandi', Jurnal Teknologi Informasi Komunikasi Pendidikan, 2(3).

Sudestia Ningsih, N. K. (2016)

'PENERAPAN METODE

COOPERATIVE LEARNING UNTUK

MENINGKATKAN KEMAMPUAN

KOGNITIF', Ilmiah Potensia, 1(2), pp. 100-106.

Wanelly, W. and Fauzan, A. (2020)

'Pengaruh Pendekatan Open Ended dan

Gaya Belajar Siswa terhadap Kemampuan

Berpikir Kreatif Matematis', Jurnal

Basicedu, 4(3), pp. 523-533. doi:

10.31004/basicedu.v4i3.388. 